\title{
Isolation and Histopathological Changes Associated with Non-Tuberculous Mycobacteria in Lymph Nodes Condemned at a Bovine Slaughterhouse
}

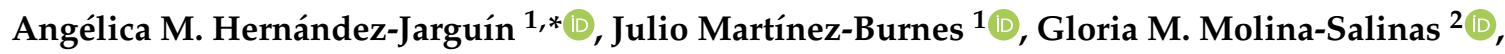 \\ Ned I. de la Cruz-Hernández ${ }^{1}$, José L. Palomares-Rangel ${ }^{1}$, Alfonso López Mayagoitia ${ }^{3}$ and \\ Hugo B. Barrios-García ${ }^{1}$ (D) \\ 1 Facultad de Medicina Veterinaria y Zootecnia, Universidad Autónoma de Tamaulipas. Cd. Victoria, \\ Tamaulipas C.P. 87000, Mexico; jmburnes@docentes.uat.edu.mx (J.M.-B.); \\ ncruz@docentes.uat.edu.mx (N.I.d.1.C.-H.); jlpalomares@docentes.uat.edu.mx (J.L.P.-R.); \\ hbarrios@docentes.uat.edu.mx (H.B.B.-G.) \\ 2 Unidad de Investigación Médica Yucatán, Unidad Médica de Alta Especialidad Hospital de Especialidades 1 \\ Mérida, Yucatán, Instituto Mexicano del Seguro Social, CP 97150, Mexico; gloria.molinas@imss.gob.mx \\ 3 Department of Pathology \& Microbiology, Atlantic Veterinary College, University of Prince Edward Island, \\ Charlottetown, PE C1A4P3, Canada; lopez@upei.ca \\ * Correspondence: amhjarguin@hotmail.com
}

Received: 28 September 2020; Accepted: 8 November 2020; Published: 10 November 2020

\begin{abstract}
Background: non-tuberculous mycobacteria (NTM) infect humans and animals and have a critical confounding effect on the diagnosis of bovine tuberculosis. The Official Mexican Standard (Norma Oficial Mexicana, NOM-ZOO-031-1995) for food safety regulates Mycobacterium bovis in cattle, but not the NTM species. The study's objective was to isolate and identify the NTM present in condemned bovine lymph nodes in a slaughterhouse, characterize the histological lesions, and correlate bacteriological and microscopic findings with the antemortem tuberculin skin test. Methods: from 528 cattle, one or two pooled samples of lymph nodes from each animal were cultured for Mycobacteria spp. and processed for histopathology. Results: mycobacteria were isolated from 54/528 (10.2\%) of the condemned lymph nodes; $25 / 54(46.2 \%)$ of these isolates were NTM; 4 bacteriological cultures with fungal contamination were discarded. Granulomatous and pyogranulomatous inflammation were present in 6/21 (28.6\%) and 7/21 (33.3\%) of the NTM-positive lymph nodes, respectively. The species of NTM associated with granulomatous lymphadenitis were M. scrofulaceum, M. triviale, M. terrae, and M. szulgai, while those causing pyogranulomatous lesions were M. szulgai, M. kansasii, M. phlei, and M. scrofulaceum. Conclusions: the NTM infections can cause false-positive results in the tuberculin test because of cross immune reactivity and interference with the postmortem identification of M. bovis in cattle.
\end{abstract}

Keywords: non-tuberculous mycobacteria; tuberculosis; granulomatous lesions; tuberculin test

\section{Introduction}

Tuberculosis (TB) is one of the most devastating zoonotic diseases that, for centuries, has afflicted humans and animals worldwide [1,2]. A report by the World Health Organization indicates that over 1.5 million people die each year because of $\mathrm{TB}$, and as many as 2 billion people are actively or silently infected [3]. The infection starts when humans or animals become exposed to genetically related species of mycobacteria, namely Mycobacterium tuberculosis, M. bovis, and the M. tuberculosis complex. These mycobacteria evade the immune and phagocytic systems and remain in infected organs for a long time, causing chronic inflammation, debilitating disease, and become a source of infection for 
other susceptible animals. For the last two decades, TB became an intrinsic part of the "One-Health" or "Global Health" perspective, where human and animal diseases are closely interconnected with the food and the environment [3].

Immunosuppression is a risk factor for TB and NTM infections [4,5]. Epidemiological studies demonstrated a relevant inter-species transmission of TB between cattle, non-bovine domestic species, and wildlife [6-8]. Transmission involving domestic and wild animals is a significant risk factor for cattle $[9,10]$. In the last decade, a transmission mode for NTM involving humans and animals has also been postulated [10]. The Mycobacterium ulcerans mode of transmission suggests that domestic animals can be infected when feeding in a contaminated environment, through simple contact with soil or feces of wild animals [11]. Humans can later be infected through direct contact with animal feces, animal bites, or ectoparasites [12,13]. In multi-host systems, sympatric hosts might also contribute to disease persistence and transmission [14,15].

Strategies to monitor and eradicate TB are underway in practically all countries around the world [3]. In Mexico, the national program for control and eradication of bovine TB started in 1990, and a few years later the guidelines for antemortem and postmortem diagnoses were streamlined under the Official Mexican Standard (Norma Oficial Mexicana, NOM-031-ZOO-1995). Antemortem detection of bovine tuberculosis is carried out using a dermal test that measures the immune response to mycobacterial antigens on the skin. For official certification, the following tests are used. The caudal fold tuberculin test (CFT) consists of the intradermal injection of $0.1 \mathrm{~mL}$ of purified bovine protein derivative (PPD) made with the strain AN5 of $M$. bovis in the caudal fold, and the cervical tuberculin test (CTT) is the intradermal injection in the mid-cervical region, with readings and measurements in millimeters, with a caliper at $72 \mathrm{~h}$ after injection. Subsequently, to evaluate the comparative cervical test, $0.1 \mathrm{~mL}$ of avian PPD made with the D4 strain of M. avium is injected intradermally in the mid-cervical area, and the reading is performed at $72 \mathrm{~h}$. Animals infected with TB show a characteristic thickening of the skin at the site of inoculation.

The postmortem detection of bovine TB is accomplished by abattoir surveillance, where meat inspectors examine organs and lymph nodes for lesions compatible with TB. Affected or enlarged tissues are condemned and submitted to the laboratory for histopathological and bacteriological analyses. Microscopically, in tissues with TB, characteristic granulomatous lesions with the presence of intralesional acid-fast bacilli are observed. The bacteriologic diagnosis of TB is based on the identification of M. bovis, either by the bacteriological culture or by PCR. Farm quarantine and meat condemnation at the slaughter plant cause significant economic losses to farmers and producers [16].

One major problem for the antemortem and postmortem diagnosis of bovine TB is the confounding effect of non-tuberculous mycobacteria (NTM), widely disseminated in the environment. Infection with NTM produces a false-positive tuberculin test because these saprophytic bacteria cross-react with the immune response to the classical tuberculous mycobacteria [17-20]. In addition to the cross immune response, the gross and microscopic lesions induced by NTM are sometimes indistinguishable from those produced by M. tuberculosis, M. bovis, and the M. tuberculosis complex $[17,18]$.

The NTM species most frequently isolated in South America and Central Africa from TB-like lesions in dairy and beef cattle are M. fortuitum, M. szulgai, M. celatum, M. terrae, M. nonchromogenicum, M. intracellulare, and M. gordonae [21-23]. The confounding effect of NTM in the antemortem and postmortem diagnosis of bovine TB is of significance in surveillance and meat inspection.

The study aimed to characterize the histological lesions in bovine lymph nodes condemned in the slaughterhouse, identify the species of NTM cultured from these nodes, and, finally, correlate the histopathological and bacteriological findings with the tuberculin tests. 


\section{Materials and Methods}

\subsection{Collection of Lymph Nodes}

As part of surveillance for the national program for control and eradication of bovine TB in Mexico, lymph nodes were condemned by certified veterinary inspectors from 528 animals, at an abattoir in Tamaulipas, between 2007 and 2011. A single or two-pooled samples of the condemned lymph nodes were submitted to the laboratory for microbiological culture and histopathology. Antemortem diagnosis of TB in animals was based on immunological response to an intradermal PPD AN5 and D4 inoculation. Lymph nodes were cut serially and examined for gross lesions compatible with TB. One-half of the lymphoid tissue was preserved in 6\% sodium borate for bacteriological analyses while the other half was immersed in $10 \%$ buffered formalin for histological examination. The specimens were sent to the Diagnostic Laboratory of the University of Tamaulipas and processed according to the Official Mexican Standard (Norma Oficial Mexicana, NOM-031-ZOO-1995).

\subsection{Mycobacterial Isolation and Biochemical Identification}

All samples were handled and processed in laminar-flow hood type II following established guidelines. After removing the sodium borate, the lymph nodes were placed in a sterile mortar where the fat was removed; the tissue was cut into small fragments and manually macerated with sterilized sand. Twenty $\mathrm{mL}$ of distilled, sterile water was added to the specimen for a second maceration. The macerate was then diluted with a $4 \%$ solution of sodium hydroxide and phenol red at a 1:1 ratio, and incubated at $37^{\circ} \mathrm{C}$ shaking for $20 \mathrm{~min}$. The suspension was centrifuged at $1157.13 \times g \times 20 \mathrm{~min}$, and, after removing the supernatant, the sediment was neutralized with a $1 \mathrm{~N}$ hydrochloric acid solution until the pink color of the indicator turned yellow, as detailed in the Petroff protocol [24].

Two Stonebrink media tubes (PRONABIVE, México City, Mexico) and one Lowenstein-Jensen culture media tube (PRONABIVE, México City, Mexico) were inoculated with the neutralized residue and incubated at $37^{\circ} \mathrm{C}$ in $5 \% \mathrm{CO}_{2}$ for nine weeks, or until typical mycobacterial colonies were observed and macroscopically characterized. Mycobacteria was first confirmed by the microscopic observation of acid-fast bacilli (AFB) using the Ziehl-Neelsen stain. Mycobacterial cultures were evaluated for metabolic activity, niacin production, and nitrate reduction, catalase production at $22{ }^{\circ} \mathrm{C}$ and $68{ }^{\circ} \mathrm{C}$, urease production, and hydrolysis of Tween 80 . Bacterial growth and tolerance were also assessed in MacConkey agar without violet crystal and 5\% sodium chloride.

\subsection{Histopathology}

Formalin-mixed lymph nodes were processed, embedded in paraffin, and cut at 4-5 $\mu \mathrm{m}$ using standard methods. Tissue sections stained with hematoxylin-eosin were microscopically evaluated for histologic lesions, and Ziehl-Neelsen stained tissues were assessed for acid-fast bacilli.

\section{Results}

\subsection{Collection of Lymph Nodes and Gross Changes}

From 528 animals with condemned lymph nodes, 235 (44.5\%) showed gross lesions compatible with TB and 42/528 (8\%) of these lymph nodes were from cattle that had tested positive for tuberculin (Table 1). 
Table 1. Total of samples, tuberculin skin tests, gross lesions, and number of mycobacteria isolated.

\begin{tabular}{cccccc}
\hline Year & $\begin{array}{c}\text { Total of } \\
\text { Samples }\end{array}$ & $\begin{array}{c}\text { Tuberculin } \\
\text { Reactors }\end{array}$ & $\begin{array}{c}\text { Gross Lesions } \\
\text { Compatible with TB }\end{array}$ & $\begin{array}{c}\text { M. bovis } \\
\text { Isolated }\end{array}$ & $\begin{array}{c}\text { NTM } \\
\text { Isolated }\end{array}$ \\
\hline 2007 & 109 & 11 & 43 & 8 & 5 \\
2008 & 169 & 13 & 69 & 12 & 6 \\
2009 & 19 & 8 & 8 & 2 & 1 \\
2010 & 139 & 2 & 67 & 3 & 5 \\
2011 & 92 & 8 & 48 & 4 & 4 \\
\hline Total & 528 & 42 & 235 & 29 & 21 \\
\hline \multicolumn{7}{r}{ TB: Tuberculosis; NTM: Non-Tuberculous Mycobacteria. }
\end{tabular}

\subsection{Mycobacterial Isolation and Biochemical Identification}

Mycobacteria were isolated from 10.2\% (54/528) of the lymph node samples; 53.7\% (29/54) of the mycobacterial isolates were identified as $M$. bovis and $46.2 \%(25 / 54)$ as NTM. Biochemical typing for 21 NTM isolates yielded M. szulgai $(\mathrm{n}=8)$, M. scrofulaceum $(\mathrm{n}=4)$, M. phlei $(\mathrm{n}=2)$, M. kansasii $(\mathrm{n}=2)$, M. chelonae $(\mathrm{n}=2)$, M. triviale $(\mathrm{n}=1), M$. fortuitum $(\mathrm{n}=1)$, and M. terrae $(\mathrm{n}=1) ; 3$ NTM isolates were discarded because fungal contamination precluded biochemical typing, and, in one case, species identification was not possible.

Incidentally, 20.0\% (5/25) of the lymph nodes harboring NTM were from animals that tested positive for the tuberculin test, and $4 \%(1 / 25)$ were from herds regarded as exposed, based on tuberculin tests.

\subsection{Histopathology}

Histopathologically, the 21 lymph nodes positive for NTM had two distinct morphologic types of inflammation: (1) granulomatous, characterized by an external rim of fibroblasts that contain macrophages, giant cells, central caseous necrosis, mineralization, and scant neutrophils; (2) pyogranulomatous inflammation, which—besides macrophages—giant cells, necrosis, and mineralization also observed abundant neutrophils. Granulomatous and pyogranulomatous inflammation were observed in $28.6 \%$ $(6 / 21)$ and $33.3 \%(7 / 21)$ of the NTM-positive lymph nodes, respectively. Necrosis and mineralization were only present in $28.6 \%$ (6/21) of the lymph nodes. Two lymph nodes $28.6 \%$ (2/7) with pyogranulomatous inflammation also had intralesional fungi. AFB were microscopically observed in $83.3 \%(5 / 6)$ of the lymph nodes showing granulomatous inflammation, and in $57.1 \%(4 / 7)$ with pyogranulomatous inflammation. Seven 33.3\% (7/21) lymph nodes yielded NTM, but did not have any microscopic lesions or changes associated with TB (Table 2).

Table 2. Association between microscopic findings and species of mycobacteria isolated.

\begin{tabular}{|c|c|c|c|}
\hline $\begin{array}{c}\text { Number of } \\
\text { Samples }\end{array}$ & $\%$ & $\begin{array}{c}\text { Microscopic } \\
\text { Changes }\end{array}$ & NTM Isolates \\
\hline 6 & 28.6 & Granulomas & M. scrofulaceum, M. triviale, M. terrae, M. szulgai. \\
\hline 7 & 33.3 & Pyogranulomas & M. szulgai, M. kansasii, M. phlei, M. scrofulaceum. \\
\hline 7 & 33.3 & Without changes & M. szulgai, M. phlei, M. chelonae, M. fortuitum, M. scrofulaceum. \\
\hline 1 & 4.8 & Unknown & M. kansasii. \\
\hline
\end{tabular}

The species of NTM associated with granulomatous lymphadenitis were M. scrofulaceum, M. triviale, M. terrae, and M. szulgai, while those related to pyogranulomatous lesions were M. szulgai, M. kansasii, M. phlei, and M. scrofulaceum. However, the NTM species, except for M. fortuitum and M. chelonae, were also isolated from lymph nodes with no microscopic lesions. Interestingly, M. scrofulaceum and M. szulgai were isolated from lymph nodes with granulomatous and pyogranulomatous inflammation, as well as from those without microscopic changes (Table 2).

Five animals were positive at the antemortem intradermal tuberculin test, and another animal belonged to a herd with positive reactors to tuberculin, which was considered "exposed." 
One tuberculin-positive animal with granulomatous lesions yielded $M$. terrae. The live animal deemed as "exposed" had pyogranulomatous inflammation and was culture-positive to M. scrofulaceum. Three tuberculin-positive animals clearly did not actively show tuberculous lesions, but yielded M. szulgai, M. phlei, and M. chelonae. On the other hand, M. kansasii was isolated from a tuberculin-positive animal, but tissues were not available for histopathology.

\section{Discussion}

\subsection{Species of NTM Isolated from Lymph Nodes}

The species of NTM isolated from the lymph nodes condemned by the meat inspectors at the slaughter plant in Tamaulipas were M. szulgai, M. scrofulaceum, M. phlei, M. kansasii, M. chelonae, M. terrae, M. triviale, and M. fortuitum.

In a review study of epidemiology of the human pulmonary infection with NTM, M. avium complex was the most common species isolated in North America, followed by M. abscessus/chelonae, M. xenopi, M. fortuitum, and M. kansasii [4]. Our findings differ from the results reported in a similar study in the south region of the State of Mexico where M. neoaurum, M. parafortuitum, M. moriokaense, and M. confluentis were the primary mycobacterial isolates [16]. Zaragoza et al. (2017) [16], using molecular markers present in the 23S rRNA gene and sequencing the 16S rRNA gene, identified the mycobacteria species in milk and nasal exudates of dairy cattle. However, it should be noted that our mycobacteria were identified by culture and came from the lymph nodes of beef cattle. Moreover, in our study, the biochemistry analysis used to identify mycobacteria could not accurately reflect the mycobacterial species. Therefore, our findings require further molecular analyses to support species identification. Nevertheless, the species of NTM reported here agree with those previously reported in Mexico in human lungs [25-28], water [29,30], and salad samples [31].

To date, the number of NTM species reported in the literature exceeds 130. According to some reports, the most common NTM isolates from cattle are M. gastri, M. flavescens, M. phlei, M. triviale, M. terrae, M. nonchromogenicum, $M$. intracellulare, M. gordonae, $M$. thermorresistible, $M$. xenopi, $M$. fortuitum, $M$. chelonae, M. ulcerans and M. kansasii, M. avium, M. neoaurum, M. confluentis, and M. vaccae [1,16,22,32-37]. It could be surmised from these findings that the environment in northern Mexico, and other regions in America, Europe, Asia, and Africa share the same species of saprophytic mycobacteria.

Tuberculous bacteria disseminate by lymphatic drainage, making the lymph nodes the prime anatomical site for meat inspection and culture. Most of the lymph nodes in our study were mesenteric and mediastinal, indicating that the main port of entry for NTM is through the lungs and digestive systems [38]. It should be noted that 33.3\% of lymph nodes without lesions, or changes associated with TB, tested positive for NTM, suggesting that lymphoid tissues harbored mycobacteria without eliciting inflammation, or that sufficient time had not elapsed after infection to trigger a microscopic inflammatory response.

\subsection{Types of Inflammation}

Enlargement of a lymph node, clinically referred to as lymphadenomegaly, is the "red flag" that prompts meat inspectors to carefully examine these tissues and look for inflammatory reactions, such as granulomas or abscesses. Histopathological and microbiological studies are indispensable to define the lesions and identify the NTM organisms correctly. The host response elicited by mycobacteria is typically granulomatous, regardless of the bacterial species or the affected organ [39]. This granulomatous inflammatory response relates mainly to the lipids in the bacterial cell wall and the mycobacteria's ability to overcome phagocytosis [39]. The deposition of mineral (calcium and phosphates) is frequent in tissues undergoing cell necrosis and chronic inflammation. This type of calcification, known as dystrophic calcification, tends to increase with time, and is not a specific lesion, since it occurs in many diseases other than tuberculosis [40]. 
It remains unclear, however, why M. scrofulaceum, M. triviale, M. terrae, and M. szulgai caused granulomatous inflammation, while M. scrofulaceum, M. kansasii, M. szulgai, and M. phlei caused a pyogranulomatous response. According to the literature, granulomatous and pyogranulomatous inflammation could be merely different stages of the inflammatory process, where pyogranulomas are less chronic and active, and granulomas more chronic and better organized [39]. Some studies with bovine lymph nodes, liver, and lungs reported that M. fortuitum, M. avium, M. kansasii, M. lentiflavum, and $M$. intracellulare were the main species associated with chronic inflammatory response and typical tuberculous granuloma formation [34-36,41]. Nonetheless, from the histopathological point of view, the lesions caused by NTM species are indistinguishable from M. tuberculosis complex [42].

The role of neutrophils in the pathogenesis of mycobacterial lesions is only partially understood. It has been observed in experimental mycobacterial infections that neutrophils favor the recruitment of other cells involved in forming granulomas [43]. The permanence of neutrophils at the site of injury depends on the production of chemical mediators, such as TNF- $\alpha$ [44]. Nonetheless, recent studies associate it mostly with interleukin-8 (IL8) [45], a potential marker for M. bovis infections [46]. Neutrophils arrive in two "waves", the first relates to the innate response against the pathogen and the second to the adaptive response [47]. As a result, neutrophils can be present in the initial host response and remain in lower numbers in chronic granulomatous inflammation.

Pyogranulomatous lymphadenitis occurs in cattle and black deer infected with M. kansasii [17,48]. This bacterium has also been isolated from left bronchial and caudal mediastinal lymph nodes from cattle [36].

Granulomatous lymphadenitis is not unique to mycobacterial infections since it also occurs with fungal and other bacterial infections. Coccidioides immitis and the algae Chlorella sp. are two systemic mycoses endemic in northern Mexico, which are important impersonators of TB. Both of these infections cause granulomatous and pyogranulomatous lymphadenitis in ruminants grossly indistinguishable from mycobacterial diseases [49,50]. In this sense, granulomatous lymphadenitis also has been described in red deer (Cervus elaphus) for apparent coinfections of Corynebacterium pseudotuberculosis, M. bovis, and M. avium subsp. paratuberculosis [51].

In this study, none of the culture tubes had colonies of different morphology. Our findings indicate that none of the isolated NTM species was part of a coinfection with organisms of the M. tuberculosis complex or another NTM species. However, there is not sufficient evidence to confirm the absence of bacterial coinfections conclusively. In the last decade coinfections of $M$. bovis and M. avium subsp. paratuberculosis in cattle (Bos taurus) and wildlife have been documented [52-55]. However, it is also well known that simultaneous mycobacterial coinfection interferes with the accurate diagnosis of bovine TB $[52,54,55]$, because a concurrent infection interferes with the diagnosis of bovine TB [52,54,55].

Moreover, NTM samples collected under field conditions are more likely to interfere with the intradermal diagnostic test for bovine TB [53]. Our findings and those reported in two studies [36,37] suggest that M. terrae, M. kansasii, M, szulgai, M. scrofulaceum, M. phlei, M. chelonae, M. engbaekii, M. arupense, M. nonchromogenicum, M. heraklionense, and M. persicum interfere in the antemortem intradermal tuberculin test for bovine TB leading to false-positives and considerable economic losses [18].

The cross-reactivity in cattle infected with $M$. bovis and NTM is a serious problem for TB surveillance and explains why the lymph nodes of few tuberculin-positive animals yielded NTM but not $M$. bovis. This cross-antigenic reaction results from the close phylogenetic relationship shared by NTM and M. tuberculosis [19,20]. NTMs and M. bovis belong to the same genus and have close phylogenetic homology, but can be differentiated by rRNA amplification [16].

Finally, lymph node enlargement is not unique to infectious diseases; it often occurs in neoplastic diseases, particularly lymphosarcoma prevalent in cattle worldwide [56]. None of the condemned specimens submitted to the laboratory in Tamaulipas had microscopic evidence of bovine lymphosarcoma or any other neoplastic disease. 


\section{Conclusions}

Based on our findings and similar reports in the literature, it is abundantly clear that NTM infections can cause false-positive results in the tuberculin test because of cross immune reactivity, and also interfere with the postmortem identification of $M$. bovis in cattle. Careful examination of lymph nodes at slaughter and laboratory testing should be routine in meat inspection.

Author Contributions: Design of the work, analysis, interpretation of data, and manuscript writing: A.M.H.-J., J.M.-B., G.M.M.-S., H.B.B.-G. Mycobacterial isolation and biochemical identification: A.M.H.-J.; histopathologic processing and evaluation: A.M.H.-J., J.M.-B., N.I.d.I.C.-H., J.L.P.-R., A.L.M.; substantial revision: A.M.H.-J., J.M.-B., G.M.M.-S., H.B.B.-G., A.L.M. All authors have read and agreed to the published version of the manuscript.

Funding: This research was funded by the project "Molecular epidemiology of Mycobacterium tuberculosis complex in strains isolated from bovines in the state of Tamaulipas" grant number TAMPS-2008-C17-107247, CONACYT.

Acknowledgments: We thank the Diagnostic Laboratory, Faculty of Veterinary Medicine and Zootechnics of the Autonomous University of Tamaulipas for the infrastructure and equipment for sample processing. We also acknowledge the support of CONACYT-México for master's studies (grant number 306393 and registration number 248068).

Conflicts of Interest: The authors declare that there is no conflict of interest regarding the publication of this paper. The funding agencies had no role in the design of the study; in the collection, analyses, or interpretation of data, in the writing of the manuscript, or in the decision to publish the results.

\section{References}

1. Bercovier, H.; Vicent, V. Mycobacterial Infections in Domestic and Wild Animals Due to Mycobacterium marinum, Mycobacterium fortuitum, Mycobacterium chelonae, Mycobacterium porcinum, Mycobacterium farcinogenes, Mycobacterium smegmatis, Mycobacterium scrofulaceum, Mycobacterium xenopi, Mycobacterium kansasii, Mycobacterium simiae and Mycobacterium genavense. Rev. Sci. Technol. 2001, 20, 265-290. [CrossRef]

2. Fonseca, K.L.; Rodrigues, P.N.; Olsson, I.A.S.; Saraiva, M. Experimental Study of Tuberculosis: From Animal Models to Complex Cell Systems and Organoids. PLoS Pathog. 2017, 13, e1006421. [CrossRef] [PubMed]

3. World Health Organization. Global Tuberculosis Report 2018; World Health Organization: Geneva, Switzerland, 2018.

4. Prevots, D.R.; Marras, T.K. Epidemiology of human pulmonary infection with nontuberculous mycobacteria: A review. Clin. Chest Med. 2015, 36, 13-34. [CrossRef] [PubMed]

5. Falkinham, J.O., III. Surrounded by Mycobacteria: Nontuberculous Mycobacteria in the Human Environment. J. Appl. Microbiol. 2009, 107, 356-367. [CrossRef] [PubMed]

6. Crispell, J.; Benton, C.H.; Balaz, D.; De Maio, N.; Ahkmetova, A.; Allen, A.; Biek, R.; Presho, E.L.; Dale, J.; Hewinson, G.; et al. Combining genomics and epidemiology to analyse bi-directional transmission of Mycobacterium bovis in a multi-host system. eLife 2019, 8, e45833. [CrossRef] [PubMed]

7. Hauer, A.; De Cruz, K.; Cochard, T.; Godreuil, S.; Karoui, C.; Henault, S.; Bulach, T.; Bañuls, A.L.; Biet, F.; Boschiroli, M.L. Genetic evolution of Mycobacterium bovis causing tuberculosis in livestock and wildlife in France since 1978. PLoS ONE 2015, 10, e0117103. [CrossRef]

8. Napp, S.; Allepuz, A.; Mercader, I.; Nofrarías, M.; López-Soria, S.; Domingo, M.; Romero, B.; Bezos, J.; De Val, B.P. Evidence of goats acting as domestic reservoirs of bovine tuberculosis. Vet. Rec. 2013, 172, 663. [CrossRef]

9. Broughan, J.M.; Judge, J.; Ely, E.; Delahay, R.J.; Wilson, G.; Clifton-Hadley, R.S.; Goodchild, A.V.; Bishop, H.; Parry, J.E.; Downs, S.H. A review of risk factors for bovine tuberculosis infection in cattle in the UK and Ireland. Epidemiol. Infect. 2016, 144, 2899-2926. [CrossRef]

10. LaHue, N.P.J.; Vicente, J.; Acevedo, P.; Gortázar, C.; Martínez-López, B. Spatially explicit modeling of animal tuberculosis at the wildlife-livestock interface in Ciudad Real province. Spain Prev. Vet. Med. 2016, 128, 101-111. [CrossRef]

11. Djouaka, R.; Zeukeng, F.; Bigoga, J.D.; Kakou-Ngazoa, S.E.; Akoton, R.; Tchigossou, G.; Coulibaly, D.N.; Tchebe, S.J.; Aboubacar, S.; Nguepdjo, C.N.; et al. Domestic animals infected with Mycobacterium ulceransImplications for transmission to humans. PLoS Negl. Trop. Dis. 2018, 12, e0006572. [CrossRef]

12. Fyfe, M.A.J.; Lavender, J.C.; Handasyde, A.K.; Legione O’Brien, R.C.; Stinear, P.T.; Pidot, J.S.; Seemann, T.; Benbow, E.M.; Wallace, R.J.; McCowan, C.; et al. A Major Role for Mammals in the Ecology of Mycobacterium ulcerans. PLoS Negl. Trop. Dis. 2010, 4, e791. [CrossRef] 
13. Durnez, L.; Katakweba, A.; Sadiki, H.; Katholi, R.C.; Kazwala, R.R.; Machang'u, R.R.; Portaels, F.; Leirs, H. Mycobacteria in Terrestrial Small Mammals on Cattle Farms in Tanzania. Vet. Med. Int. 2011, $2011,12$. [CrossRef] [PubMed]

14. Webster, J.P.; Borlase, A.; Rudge, J.W. Who acquires infection from whom and how? Disentangling multi-host and multi-mode transmission dynamics in the 'elimination' era. PhilOS. Trans. R. Soc. B 2017, 372, 20160091. [CrossRef] [PubMed]

15. Barasona, J.A.; Gortázar, C.; de la Fuente, J.; Vicente, J. Host richness increases tuberculosis disease risk in game-managed areas. Microorganisms 2019, 7, 182. [CrossRef]

16. Zaragoza Bastida, A.; Rivero Pérez, N.; Valladares Carranza, B.; Isaac-Olivé, K.; Moreno Pérez, P.; Sandoval Trujillo, H.; Ramírez Durán, N. Molecular Identification of Mycobacterium Species of Public Health and Veterinary Importance from Cattle in the South State of Mexico. Can. J. Infect. Dis. Med. Microbiol. 2017, 2017, 6094587. [CrossRef] [PubMed]

17. Waters, W.R.; Whelan, A.O.; Lyashchenko, K.P.; Greenwald, R.; Palmer, M.V.; Harris, B.N.; Hewinson, R.G.; Vordermeier, H.M. Immune Responses in Cattle Inoculated with Mycobacterium bovis, Mycobacterium tuberculosis, or Mycobacterium kansasii. Clin. Vaccine Immunol. 2010, 17, 247-252. [CrossRef] [PubMed]

18. Waters, W.R.; Palmer, M.V.; Thacker, T.C.; Payeur, J.B.; Harris, N.B.; Minion, F.C.; Greenwald, R.; Esfandiari, J.; Andersen, P.; McNair, J.; et al. Immune Responses to Defined Antigens of Mycobacterium bovis in Cattle Experimentally Infected with Mycobacterium kansasii. Clin. Vaccine Immunol. 2006, 13, 611-619. [CrossRef] [PubMed]

19. Van Ingen, J.; de Zwaan, R.; Dekhuijzen, R.; Boeree, M.; van Soolingen, D. Region of Difference 1 in Nontuberculous Mycobacterium Species Adds a Phylogenetic and Taxonomical Character. J. Bacteriol. 2009, 191, 5865-5867. [CrossRef]

20. Devulver, G.; de Montclos, M.P.; Flandrois, J.P. A Multigene Approach to Phylogenetic Analysis Using the Genus Mycobacterium as a Model. Int. J. Syst. Evol. Microbiol. 2005, 55, 293-302. [CrossRef]

21. Pardo, R.B.; Langoni, H.; Mendonça, L.J.; Chi, K.D. Isolation of Mycobacterium spp. in milk from cows suspected or positive to tuberculosis. Braz. J. Vet. Res. Anim. Sci. 2001, 38, 284-287. [CrossRef]

22. Proaño-Perez, F.; Rigouts, L.; Brandt, J.; Dorny, P.; Ron, J.; Chavez, M.A.; Rodriguez, R.; Fissette, K.; van Aerde, A.; Portaels, F.; et al. Preliminary Observations on Mycobacterium spp. in Dairy Cattle in Ecuador. Am. J. Trop. Med. Hyg. 2006, 75, 318-323. [CrossRef] [PubMed]

23. Rigouts, L.; Maregeya, B.; Traore, H.; Collart, J.P.; Fissette, K.; Portaels, F. Use of DNA Restriction Fragment Typing in the Differentiation of Mycobacterium tuberculosis Complex Isolates from Animals and Humans in Burundi. Tuber. Lung Dis. 1996, 77, 264-268. [CrossRef]

24. Buijtles, P.C.; Petit, P.L. Comparison of NaOH-N-Acetyl Cysteine and Sulfuric Acid Decontamination Methods for Recovery of Mycobacteria from Clinical Specimens. J. Microbiol. Methods 2005, 62, 83-88. [CrossRef] [PubMed]

25. Pérez-Martínez, I.; Ponce-De-León, A.; Bobadilla, M.; Villegas-Sepúlveda, N.; Pérez-García, M.; Sifuentes-Osornio, J.; González-y-Merchand, J.A.; Estrada-García, T. A Novel Identification Scheme for Genus Mycobacterium, M. Tuberculosis Complex, and Seven Mycobacteria Species of Human Clinical Impact. Eur. J. Clin. Microbiol. Infect. Dis. 2008, 27, 451. [CrossRef] [PubMed]

26. Cortés-Torres, N.; González-y-Merchand, J.A.; González-Bonilla, C.; García-Elorriaga, G. Molecular Analysis of Mycobacteria Isolated in Mexican Patients with Different Immunodeficiencies in a Tertiary Care Hospital. Arch. Med. Res. 2013, 44, 562-569. [CrossRef]

27. Escobar-Escamilla, N.; Ramírez-González, J.E.; González-Villa, M.; Torres-Mazadiego, P.; Mandujano-Martínez, A.; Barrón-Rivera, C.; Bäcker, C.E.; Fragoso-Fonseca, D.E.; Olivera-Díaz, H.; Alcántara-Pérez, P.; et al. Hsp65 Phylogenetic Assay for Molecular Diagnosis of Nontuberculous Mycobacteria Isolated in Mexico. Arch. Med. Res. 2014, 45, 90-97. [CrossRef] [PubMed]

28. Orduña, P.; Castillo-Rodal, A.I.; Mercado, M.E.; Ponce de León, S.; López-Vidal, Y. Specific Proteins in Nontuberculous Mycobacteria: New Potential Tools. Biomed Res. Int. 2015, 2015, 964178. [CrossRef]

29. Castillo-Rodal, A.I.; Mazari-Hiriart, M.; Lloret-Sánchez, L.T.; Sachman-Ruiz, B.; Vinuesa, P.; López-Vidal, Y. Potentially Pathogenic Nontuberculous Mycobacteria Found in Aquatic Systems. Analysis from a Reclaimed Water and Water Distribution System in Mexico City. Eur. J. Clin. Microbiol. Infect. Dis. 2012, 31, 683-694. [CrossRef] 
30. Perez-Martinez, I.; Aguilar-Ayala, D.A.; Fernandez-Rendon, E.; Carrillo-Sanchez, A.K.; Helguera-Repetto, A.C.; Rivera-Gutierrez, S.; Estrada-Garcia, T.; Cerna-Cortes, J.F.; Gonzalez-Y-Merchand, J.A. Occurrence of Potentially Pathogenic Nontuberculous Mycobacteria in Mexican Household Potable Water: A Pilot Study. BMC Res. Notes 2013, 6, 531. [CrossRef]

31. Cerna-Cortes, J.F.; Leon-Montes, N.; Cortes-Cueto, A.L.; Salas-Rangel, L.P.; Helguera-Repetto, A.C.; Lopez-Hernandez, D.; Rivera-Gutierrez, S.; Fernandez-Rendon, E.; Gonzalez-y-Merchand, J.A. Microbiological Quality of Ready-to-Eat Vegetables Collected in Mexico City: Occurrence of Aerobic-Mesophilic Bacteria, Fecal Coliforms, and Potentially Pathogenic Nontuberculous Mycobacteria. Biomed Res. Int. 2015, 2015, 1-9. [CrossRef]

32. Gortazar, C.; Torres, M.J.; Acevedo, P.; Aznar, J.; Negro, J.J.; de la Fuente, J.; Vicente, J. Fine-Tuning the Space, Time, and Host Distribution of Mycobacteria in Wildlife. BMC Microbiol. 2011, 11, 27. [CrossRef] [PubMed]

33. Biet, F.; Boschiroli, M.L. Non-Tuberculous Mycobacterial Infections of Veterinary Relevance. Res. Vet. Sci. 2014, 97, S69-S77. [CrossRef] [PubMed]

34. Katale, B.Z.; Mbugi, E.V.; Botha, L.; Keyyu, J.D.; Kendall, S.; Dockrell, H.M.; Michel, A.L.; Kazwala, R.R.; Rweyemamu, M.M.; van Helden, P.; et al. Species Diversity of Non-Tuberculous Mycobacteria Isolated from Humans, Livestock and Wildlife in the Serengeti Ecosystem, Tanzania. BMC Infect. Dis. 2014, 14, 616. [CrossRef] [PubMed]

35. Cheng, G.; Xu, D.; Wang, J.; Liu, C.; Zhou, Y.; Cui, Y.; Liu, H.; Wan, K.; Zhou, X. Isolation and Identification of Multiple Drug Resistant Nontuberculous Mycobacteria from Organs of Cattle Produced Typical Granuloma Lesions. Microb. Pathog. 2017, 107, 313-316. [CrossRef]

36. Ghielmetti, G.; Friedel, U.; Scherrer, S.; Sarno, E.; Landolt, P.; Dietz, O.; Hilbe, M.; Zweifel, C.; Stephan, R. Non-Tuberculous Mycobacteria Isolated from Lymph Nodes and Faecal Samples of Healthy Slaughtered Cattle and the Abattoir Environment. Transbound. Emerg. Dis. 2018, 65, 711-718. [CrossRef]

37. Bolaños, C.A.D.; Franco, M.M.J.; Souza Filho, A.F.; Ikuta, C.Y.; Burbano-Rosero, E.M.; Ferreira Neto, J.S.; Heinemann, M.B.; Motta, R.G.; Paula, C.L.; Morais, A.B.C.; et al. N Nontuberculous Mycobacteria in Milk from Positive Cows in the Intradermal Comparative Cervical Tuberculin Test: Implications for Human Tuberculosis Infections. Rev. Inst. Med. Trop. Sao Paulo 2018, 60, e6. [CrossRef]

38. Belachew, T. Review on Bovine Tuberculosis. Dairy Vet. Sci. J. 2017, 3, 555611. [CrossRef]

39. Ackerman, M.R. Inflammation and Healing. In Pathologic Basis of Veterinary Disease; Zachary, J.F., Ed.; Elsevier: Amsterdam, The Netherlands, 2017; pp. 73-131.

40. Miller, M.A.; Zachary, J.F. Pathologic Basis of Veterinary Disease. Zachary, J.F., Ed.; Elsevier: Amsterdam, The Netherlands, 2017; pp. 2-43.

41. Gcebe, N.; Hlokwe, T.M. Non-tuberculous Mycobacteria in South African Wildlife: Neglected Pathogens and Potential Impediments for Bovine Tuberculosis Diagnosis. Front. Cell. Infect. Microbiol. 2017, 7, 15. [CrossRef]

42. Piersimoni, C.; Scarparo, C. Pulmonary infections associated with nontuberculous mycobacteria in immunocompetent patients. Lancet Infect Dis. 2008, 8, 323-334. [CrossRef]

43. Je, S.; Quan, H.; Na, Y.; Cho, S.N.; Kim, B.J.; Seok, S.H. An In Vitro Model of Granuloma-Like Cell Aggregates Substantiates Early Host Immune Responses Against Mycobacterium Massiliense Infection. Biol. Open 2016, 5, 1118-1127. [CrossRef]

44. Kasahara, K.; Sato, I.; Ogura, K.; Takeuchi, H.; Kobayashi, K.; Adachi, M. Expression of chemokines and induction of rapid cell death in human blood neutrophils by Mycobacterium tuberculosis. J. Infect. Dis. 1998, 178, 127-137. [CrossRef] [PubMed]

45. Chakraborty, P.; Kulkarni, S.; Rajan, R.; Sainis, K. Mycobacterium Tuberculosis Strains from Ancient and Modern Lineages Induce Distinct Patterns of Immune Responses. J. Infect. Dev. Ctries. 2018, 11, 904-911. [CrossRef] [PubMed]

46. Gao, X.; Guo, X.; Li, M.; Jia, H.; Lin, W.; Fang, L.; Jiang, Y.; Zhu, H.; Zhang, Z.; Ding, J.; et al. Interleukin 8 and Pentaxin (C-Reactive Protein) as Potential New Biomarkers of Bovine Tuberculosis. J. Clin. Microbiol. 2019, 57, e00274-19. [CrossRef] [PubMed]

47. Remot, A.; Doz, E.; Winter, N. Neutrophils and Close Relatives in the Hypoxic Environment of the Tuberculous Granuloma: New Avenues for Host-Directed Therapies? Front. Immunol. 2019, 10, 417. [CrossRef] [PubMed]

48. Hall, P.B.; Bender, L.; Garner, M.M. Mycobacteriosis in a Black-Tailed Deer (Odocoileus hemionus colombianus) Caused by Mycobacerium kansasii. J. Zoo Wildl. Med. 2005, 36, 115-117. [CrossRef] 
49. Reyes-Montes, M.R.; Pérez-Huitrón, M.A.; Ocaña-Monroy, J.L.; Frías-De-León, M.G.; Martínez-Herrera, E.; Arenas, R.; Duarte-Escalante, E. The habitat of Coccidioides spp. and the role of animals as reservoirs and disseminators in nature. BMC Infect. Dis. 2016, 16, 550. [CrossRef]

50. Ramírez-Romero, R.; Rodríguez-Tovar, L.E.; Nevárez-Garza, A.M.; López, A. Chlorella Infection in a Sheep in Mexico and Minireview of Published Reports from Humans and Domestic Animals. Mycopathologia 2010, 169, 461-466. [CrossRef]

51. Matos, A.C.; Dias, A.P.; Morais, M.; Figueira, L.; Martins, M.H.; Matos, M.; Pinto, M.L.; Coelho, A.C. Granuloma Coinfection with Mycobacterium bovis, Mycobacterium avium subsp. paratuberculosis and Corynebacterium pseudotuberculosis in Five Hunted Red Deer (Cervus elaphus) in Portugal. J. Wildl. Dis. 2015, 51, 793-794. [CrossRef] [PubMed]

52. Barry, C.; Corbett, D.; Bakker, D.; Andersen, P.; McNair, J.; Strain, S. The Effect of Mycobacterium avium complex Infections on Routine Mycobacterium bovis Diagnostic Tests. Vet. Med. Int. 2011, 2011, 1-7. [CrossRef]

53. Boadella, M.; Lyashchenko, K.; Greenwald, R.; Esfandiari, J.; Jaroso, R.; Carta, T.; Garrido, J.M.; Vicente, J.; de la Fuente, J.; Gortázar, C. Serologic Tests for Detecting Antibodies against Mycobacterium bovis and Mycobacterium avium subspecies paratuberculosis in Eurasian Wild Boar (Sus scrofa scrofa). J. Vet. Diagn. Investig. 2011, 23, 77-83. [CrossRef] [PubMed]

54. Thacker, T.C.; Robbe-Austerman, S.; Harris, B.; van Palmer, M.; Waters, W.R. Isolation of Mycobacteria from Clinical Samples Collected in the United States from 2004 to 2011. BMC Vet. Res. 2013, 9, 100. [CrossRef] [PubMed]

55. Seva, J.; Sanes, J.M.; Ramis, G.; Mas, A.; Quereda, J.J.; Villarreal-Ramos, B.; Villar, D.; Pallares, F.J. Evaluation of the Single Cervical Skin Test and Interferon Gamma Responses to Detect Mycobacterium bovis Infected Cattle in a Herd Co-Infected with Mycobacterium avium subsp. paratuberculosis. Vet. Microbiol. 2014, 171, 139-146. [CrossRef] [PubMed]

56. Hishamnuri, W.N.; Nakagun, S.; Maezawa, M.; Sakaguchi, K.; Akiyama, N.; Watanabe, K.I.; Horiuchi, N.; Kobayashi, Y.; Inokuma, H. Disseminated thymic B-cell lymphoma in a Holstein heifer. J. Vet. Diagn. Investig. 2019, 31, 852-855. [CrossRef] [PubMed]

Publisher's Note: MDPI stays neutral with regard to jurisdictional claims in published maps and institutional affiliations.

(C) 2020 by the authors. Licensee MDPI, Basel, Switzerland. This article is an open access article distributed under the terms and conditions of the Creative Commons Attribution (CC BY) license (http://creativecommons.org/licenses/by/4.0/). 